Sains Malaysiana 49(9)(2020): 2073-2081

http://dx.doi.org/10.17576/jsm-2020-4909-05

\title{
Effects of Sulphuric Acid Concentrations during Solvolysis Process of Carbon Fiber Reinforced Epoxy Composite
}

(Kesan Kepekatan Asid Sulfurik semasa Proses Solvolisis Komposit Epoksi yang Diperkuat oleh Gentian Karbon)

\author{
Muhammad Falaq Muhammad Faisal, Azman Hassan*, Khong Wui Gan, Mohd Nazrul Roslan \& Azrin \\ HANI ABDUL RASHID
}

\begin{abstract}
Developing a cost-effective technique of reclaiming carbon fibers without significantly deteriorating their quality has gained much importance. This paper reports on reclaiming carbon fibers from the carbon fiber reinforced polymer (CFRP) by solvolysis technique using sulphuric acid. The main objective of this work was to determine the lowest sulphuric acid concentration which can remove the epoxy resin from the composites, at room temperature and atmospheric pressure. The sulphuric acid concentrations used ranged from 11 to $18 \mathrm{~mol} \mathrm{~L}^{-1}$ with 30 min reaction time and $50 \mathrm{~mL}$ volume. Thermogravimetric analysis (TGA) showed that the fiber content of the composites is $68 \%$ by weight. From the solvolysis process, mass of decomposed epoxy resin decreased with decreasing acid concentrations. SEM images show that the residual epoxy adhering to the fibers after solvolysis increased with decreasing molarity. Acid concentrations lower than $15 \mathrm{M}$ were found to be not effective in removing the epoxy resin from the carbon fibers. The tensile strength and Young's modulus of all the reclaimed fibers is marginally lower than the untreated carbon fibers. The tensile strength was found to increase as the acid concentration decreases with fibers in $15 \mathrm{M}$ acid showed the highest tensile strength of $3.43 \mathrm{GPa}$ (99.1\% strength retention). Similar trend was also observed for Young's modulus. The study shows the potential of sulphuric acid to reclaim carbon fiber from the CFRP with $15 \mathrm{M}$ giving the optimum properties in terms of tensile properties retention and epoxy resin decomposition.
\end{abstract}

Keywords: Carbon fiber reinforced polymer; epoxy resin; solvolysis; sulphuric acid; tensile properties

\section{ABSTRAK}

Penghasilan teknik yang kos efektif untuk memperoleh gentian karbon tanpa mengurangkan kualiti secara ketara telah menjadi semakin penting. Kertas ini melaporkan tentang perolehan gentian karbon daripada gentian karbon diperkuatkan dengan polimer (CFRP) melalui teknik solvolisis menggunakan asid sulfurik. Objektif utama kerja ini adalah untuk menentukan kepekatan asid sulfurik terendah yang boleh menguraikan resin epoksi daripada komposit pada suhu bilik dan tekanan atmosfera. Kepekatan asid sulfurik yang digunakan dalam julat antara 11 dan 18 mol $L^{-1}$ dengan masa tindak balas $30 \mathrm{~min}$ dan isi padu $50 \mathrm{~mL}$. Analisis Termogravimetrik (TGA) menunjukkan bahawa kandungan gentian adalah 68\% daripada berat komposit. Daripada proses solvolisis, jisim resin epoksi yang terurai berkurangan dengan berkurangnya kepekatan asid. Imej SEM menunjukkan baki epoksi yang melekat pada gentian selepas solvolis bertambah dengan berkurangnya molariti. Pada kepekatan asid kurang daripada 15 M, didapati tidak berkesan dalam menguraikan resin epoksi daripada gentian karbon. Kekuatan tegangan dan modulus Young untuk semua gentian yang diperoleh adalah sedikit rendah daripada gentian karbon yang tidak dirawat. Kekuatan tegangan menunjukkan peningkatan apabila kepekatan asid berkurang dengan gentian dalam asid 15 M menunjukkan kekuatan tegangan tertinggi iaitu 3.43 GPa (99.1\% pengekalan kekuatan). Aliran sama ditunjukkan untuk modulus Young. Kajian ini menunjukkan asid sulfurik berpotensi untuk memperoleh gentian karbon daripada CFRP dengan 15 M memberikan keadaan paling optimum daripada segi pengekalan kekuatan tegangan dan pemisahan resin epoksi.

Kata kunci: Asid sulfurik; polimer diperkuat gentian karbon dikitar semula; resin epoksi; sifat mekanikal; solvolis

\section{INTRODUCTION}

Epoxy resins are widely used in composites due to their excellent mechanical and electrical performance. Various reinforcing agents such as carbon fibers, glass fibers and kenaf's have been incorporated to further improve the properties and overcome their disadvantages such as brittleness (Ismail et al. 2018; Vazquez-Moreno et al. 2019; Zhao et al. 2019). Carbon fiber reinforced polymer composites (CFRP) have gained much attention due to their extensive properties such as high strength, low 
density, and good resistance to corrosion (Pickering 2006). More carbon fiber composites have been manufactured and increasingly applied in industrial sectors such as aerospace, automotive, renewable energy, and sports (Rybicka et al. 2016; Su 2014). Holmes (2014) estimated that the global demand for CFRP to rise to 146000 tonnes by 2020 . Due to that, substantial amounts of composite waste generated due to manufacturing process, off-cuts as well as end-of-life products are to increase significantly in the coming years. Therefore, in order to achieve sustainable composite manufacturing, it is necessary to find ways to recycle composite waste instead of sending it to landfill or incinerator for disposal (Bai et al. 2010a). By efficient recycling, these carbon fibers could be reused in other applications by mixing it with thermoplastics to create a new composite (Mohd Ishak 2019). This will give advantages towards conserving the environment as well as reducing the cost to produce a new composite (Witik et al. 2013).

There are three common methods used to recycle composites namely, thermal, mechanical, and solvolysis processes (Oliveux et al. 2015). Other recycling methods such as microwave (Deng et al. 2019) and sonochemical (Das \& Varughese 2016) treatments have also been reported. In thermal processing method, the carbon fibers were reclaimed by subjecting the composite at a high temperature to decompose polymer resin. Thermal processing includes fluidized bed reaction process (Meng et al. 2017) and pyrolysis (Jiang \& Pickering 2016; Onwudili et al. 2013). This method has the ability to reclaim not only the fibers, but also the liquid and the gases decomposed from the resin which could be reused for other applications (Cunliffe et al. 2003). However, the use of high temperature (up to $700{ }^{\circ} \mathrm{C}$ ) can result in fibers with lower mechanical strength retention and contamination due to char deposition (Shibata et al. 2013). Mechanical recycling involves cutting the composite into smaller pieces by means of shredding, grinding, cutting or other related mechanical processes (Kouparitsas et al. 2002; Li et al. 2016; Palmer et al. 2010). One of the disadvantages of this method is that the process results in much finer unseparated products which includes both the resin matrices and the fibers (Palmer et al. 2009).

Solvolysis has been regarded as one of the techniques that is promising in recycling composites. In a solvolysis process, solvents are used to degrade and decompose the resin to reclaim the fibers. Studies of solvolysis using supercritical solvents such as water (Bai et al. 2010b; Princaud et al. 2014) and alcohols (Jiang et al. 2009; Yan et al. 2014) have been shown promising since they could almost fully decompose all resins with the reclaimed fibers having mechanical properties comparable to the virgin fibers (Asmatulu et al. 2014). However, in order to ensure its supercritical state, this method must be carried out in a high temperature and high-pressure environment which is very costly (Shibata et al. 2013). Other solvents have also been used for solvolysis at elevated temperatures which include sodium hydroxide (Yang et al. 2014), acetone (Keith et al. 2018) and acetic acid (Wang et al. 2015). Considering these factors, we propose a solvolysis method which uses a solvent that will reclaim the fibers at room temperature and atmospheric pressure conditions from the CFRP. To the best of our knowledge, limited studies have been reported on using solvent in solvolysis process at room temperature and atmospheric pressure to reclaim carbon fibers from epoxy composites. Previously, nitric acid was used to decompose the epoxy resin from the CFRP but it was done at a higher temperature (Dang et al. 2002). No study has reported on the use of acid at room temperature and atmospheric pressure. Therefore, in this study sulphuric acid which is a reactive acid has been proposed to be used as the solvent in the solvolysis process.

The objective of this study was to determine the lowest sulphuric acid concentration that is capable of removing all the epoxy resin while maintaining good tensile properties of the carbon fiber. Sulphuric acid at different concentrations ( 11 to $18 \mathrm{M}$ ) was used to treat the epoxy composites at room temperature and atmospheric pressure. Deionized water was used for dilution with parameters such as solvent volume $(50 \mathrm{~mL})$, time ( $30 \mathrm{~min})$ and temperature (room temperature) being set constant. The reclaimed fibers from the solvolysis were then tested with single fiber tensile test to investigate the retention of their mechanical properties. Thermogravimetric analysis (TGA) was also performed on the original composite sample to determine independently its carbon fiber mass fraction, which can then be used as the reference value to compare with the mass obtained from the solvolysis process.

\section{MATERIALS AND METHODS}

In this study, the CFRP used was expired unidirectional carbon fiber reinforced epoxy resin composites (MTM58FRB/HS(24K)450-38\%RW) prepreg system supplied by Solvay which was left outside the freezer and cured under room temperature for a month. Sulphuric acid $(96 \% \mathrm{w} / \mathrm{w})$ was used as the solvent for the solvolysis process which was supplied by QREc Chemicals. The molarity of the sulphuric acid used is $18 \mathrm{~mol} \mathrm{~L}^{-1}$ (18 $\mathrm{M})$. Untreated fibers were used as a comparison to the fibers obtained from solvolysis. They were extracted directly with care using tweezers from the free edge of the composite prepreg without undergoing solvolysis process.

\section{SOLVOLYSIS OF CFRP}

A small piece of CFRP of $50 \times 25 \times 0.5 \mathrm{~mm}$ was cut and put in $50 \mathrm{~mL}$ of concentrated sulphuric acid $(18 \mathrm{M})$ which was stirred slowly using a magnetic stirrer at room 
temperature. After $30 \mathrm{~min}$, the sample was cleaned and washed with acetone and deionized water. The sample was then dried in an oven at $80{ }^{\circ} \mathrm{C}$ for $12 \mathrm{~h}$ to remove all moisture from the composite. For 17, 16, 15, 14, 13, 12, and $11 \mathrm{M}$ concentrations, the sulphuric acid was diluted using distilled water according to the formula (1)

$$
\mathrm{M}_{1} \mathrm{~V}_{1}=\mathrm{M}_{2} \mathrm{~V}_{2}
$$

where $M_{1}$ is the concentration of concentrated acid (18 $\mathrm{M}) ; \mathrm{V}_{1}$ is the required volume of sulphuric acid; $\mathrm{M}_{2}$ is the concentration of the required diluted solution (11 - 17 $\mathrm{M})$; and $\mathrm{V}_{2}$ is the volume of the diluted solution $(50 \mathrm{~mL})$.

The percent mass retention was calculated using (2)

$\%$ mass retention $=\left(\mathrm{m}_{2} / \mathrm{m}_{1}\right) \times 100 \%$

where $\mathrm{m}_{1}$ represent the initial mass of the composite; and $\mathrm{m}_{2}$ is the residual mass after solvolysis.
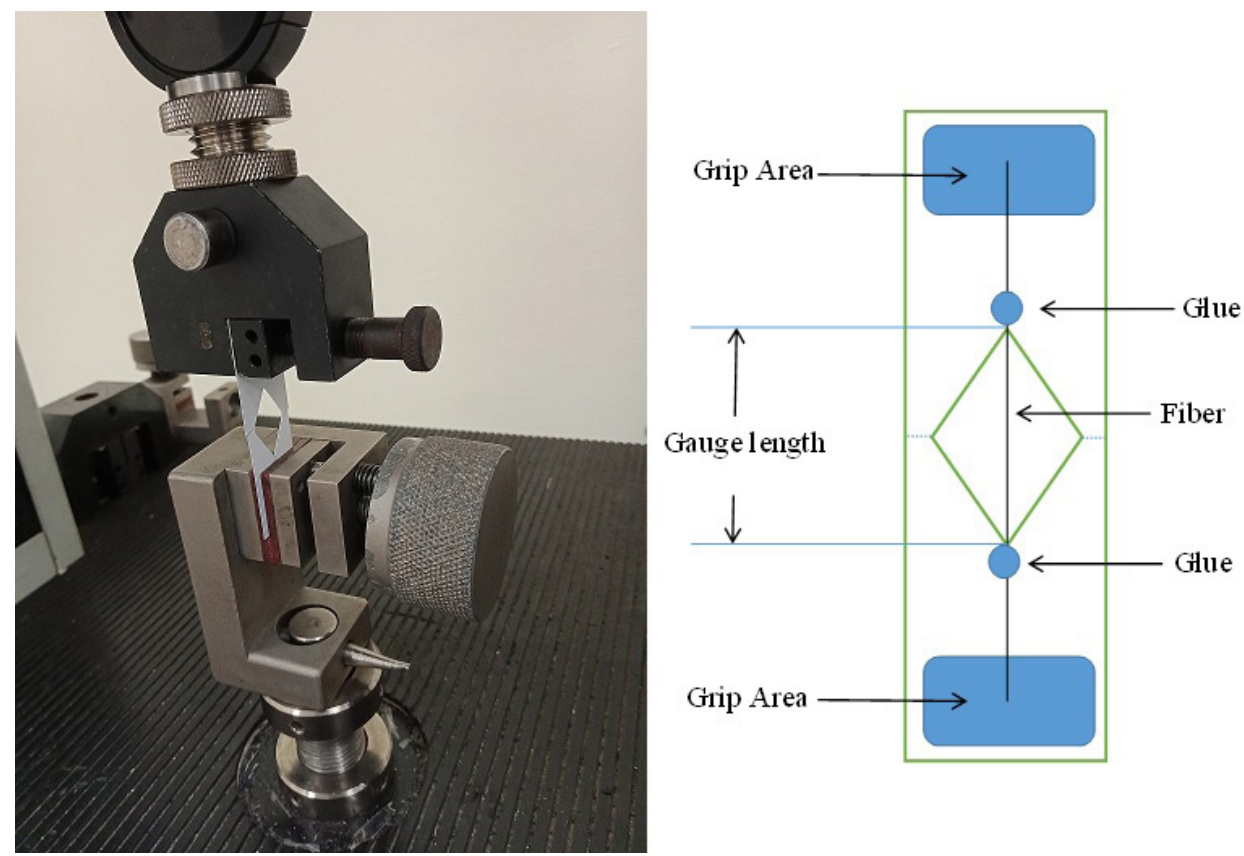

FIGURE 1. Single fiber tensile test set-up (left) and mounting tab (right)

\section{SCANNING ELECTRON MICROSCOPY AND \\ THERMOGRAVIMETRIC ANALYSIS}

Surface characterizations and the diameter of the fibers were determined using a variable pressure scanning electron microscope (VP-SEM, JOEL iT300) while the thermal decomposition of the CFRP were performed using thermal gravimetric analyzer (Perkin Elmer, TGA 4000) from room temperature to $800{ }^{\circ} \mathrm{C}$ under nitrogen condition

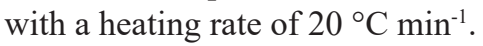

The acid digestion process was repeated with 3 specimens for each acid concentration.

\section{SINGLE FIBER TENSILE TEST}

To evaluate the effect of solvolysis towards the carbon fiber, tensile strength of the fibers was characterized using single fiber tensile test. It was carried out using universal testing machine LLYODS instruments LR30K according to the standard ASTM-C1557 (ASTM International 2012). A single fiber filament was glued by epoxy adhesive and aligned onto a cardboard mounting tab. The mounting tab was then fixed onto the machine. The gauge length of the fiber is $20 \mathrm{~mm}$ and the crosshead speed were set at $1 \mathrm{~mm}$ $\min ^{-1}$. Both sides of the mounting tab were carefully cut at the middle-gauge point to leave the filament suspended between the grips of the machine. The carbon fiber was then loaded until failure, and the force-displacement curve was plotted. At least 25 filaments were tested for each case of acid concentration. The mounting tab and its set-up onto the tensile machine are shown in Figure 1. 
the TGA shows a sudden a drop in weight percentage at around $350{ }^{\circ} \mathrm{C}$, indicating the rapid decomposition of the resin. It stops at around $600{ }^{\circ} \mathrm{C}$ where the decomposition process slows down and the residual weight remains constant at around $68 \%$ indicating that the resin on the composite have almost fully degraded and only carbon fibers remains. This value is consistent with the value from Table 1 for mass percent retention for the case of solvolysis at $18 \mathrm{M}$ which is $69.9 \%$, suggesting that most of the epoxy resin from the composite was completely degraded. The higher mass percent retention for the cases of acid concentrations of $17 \mathrm{M}$ and below shown in
Table 1 indicates that there is increasing amount of resin residue on the fibers with decreasing acid concentration after the solvolysis process. Although there was resin residue adhering to the surface of the carbon fibers, most of the fibers could still be easily separated and extracted from the composite for further analyses, especially for the cases of acid concentration $15 \mathrm{M}$ and above.

For the solvolysis using lower acid concentrations of $14,13,12$, and $11 \mathrm{M}$, the percentage of mass retention is very high, i.e. more than $90 \%$, which indicates that there is essentially no effective decomposition of the resin from the composites by the acid.

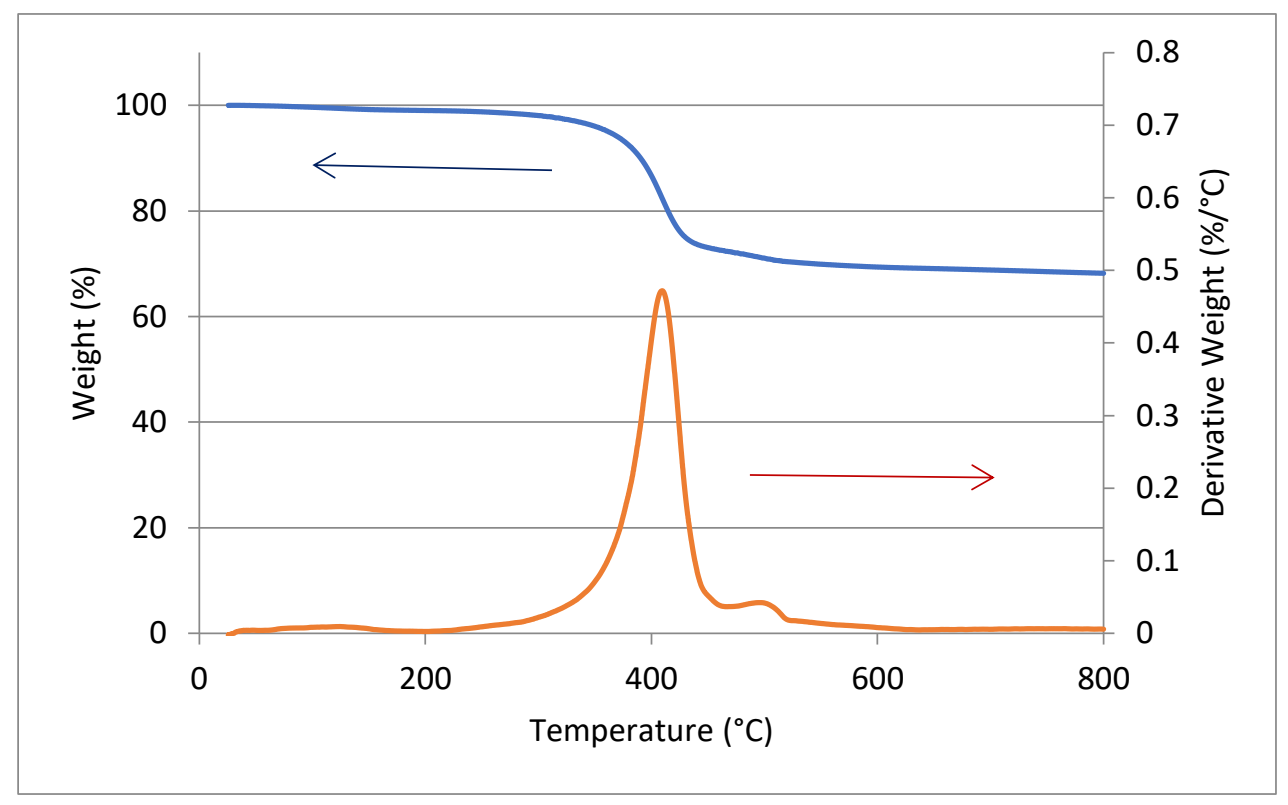

FIGURE 2.TGA curve of CFRP in nitrogen atmosphere

TABLE 1. Mass retention of CFRP from solvolysis

\begin{tabular}{ccccccccc}
\hline $\begin{array}{c}\text { Sample in acid } \\
\text { concentration (M) }\end{array}$ & 18 & 17 & 16 & 15 & 14 & 13 & 12 & 11 \\
\hline Mass retention (\%) & 69.9 & 77.4 & 79.2 & 85.6 & 93.7 & 96.6 & 98.2 & 99.0 \\
\hline
\end{tabular}

\section{TENSILE PROPERTIES}

Table 2 shows the tensile strength and the Young's modulus of the untreated fiber and fibers reclaimed from the composites through solvolysis technique at different acid concentrations. From the table, it can be observed that the tensile strength and the Young's modulus decreased with increasing acid concentration. The highest value for the tensile strength is obtained for carbon fibers treated with acid concentration of $15 \mathrm{M}$, which is $3.43 \mathrm{GPa}$ with tensile strength retention of $99.1 \%$. As the acid concentration increased to $16 \mathrm{M}$ and $17 \mathrm{M}$ there is only a slight decrease of tensile strength retention of 98.6 and 
$96.5 \%$, respectively. Carbon fibers in acid concentration of $18 \mathrm{M}$ yield the lowest tensile strength of $3.26 \mathrm{GPa}$ with tensile strength retention of $94.2 \%$, suggesting that high concentration acid could degrade significantly the strength of the reclaimed carbon fibers.

The losses of tensile strength due to the effect of acid solvolysis are comparable in terms of percentage of tensile strength recovery with the results by other researchers who used solvolysis in recycling CFRP. Jiang et al. (2017) who pretreated the composite with nitric acid and sulphuric acid and then used potassium hydroxide as the main solvent retained $95.6 \%$ of its tensile strength while Wang et al. (2015) who used acetic acid has a tensile strength recovery of $97.6 \%$. Yang et al. (2014) studied the use of polyethylene glycol combined with sodium hydroxide to degrade the resin at $200{ }^{\circ} \mathrm{C}$. They found a larger loss of tensile with strength recovery of about $93 \%$.

As for the Young's modulus, the highest value is for carbon fibers in acid concentration of $15 \mathrm{M}$ which is $226.7 \mathrm{GPa}$ (97.4\% modulus retention) while the lowest value is for $18 \mathrm{M}$ which is $221.1 \mathrm{GPa}(95.0 \%$ modulus retention). The values of the Young's modulus of the reclaimed carbon fibers are only slightly lower than that of the untreated fiber which is $237.7 \mathrm{GPa}$, suggesting that there is no significant difference in stiffness of the fibers after solvolysis at different acid concentrations.

TABLE 2. Single fiber tensile test results

\begin{tabular}{|c|c|c|c|c|}
\hline $\begin{array}{l}\text { Samples in acid } \\
\text { concentration }(\mathrm{M})\end{array}$ & Diameter $(\mu \mathrm{m})$ & $\begin{array}{l}\text { Maximum load } \\
\text { (N) }\end{array}$ & $\begin{array}{l}\text { Tensile strength } \\
\qquad(\mathrm{GPa})\end{array}$ & $\begin{array}{l}\text { Young's modulus } \\
\text { (GPa) }\end{array}$ \\
\hline 18 & $7.16 \pm 0.12$ & $0.1313 \pm 0.0142$ & $3.26 \pm 0.35$ & $221.1 \pm 19.9$ \\
\hline 17 & $7.17 \pm 0.15$ & $0.1350 \pm 0.0093$ & $3.34 \pm 0.23$ & $223.8 \pm 15.8$ \\
\hline 16 & $7.15 \pm 0.22$ & $0.1367 \pm 0.0117$ & $3.41 \pm 0.29$ & $225.1 \pm 21.5$ \\
\hline 15 & $7.13 \pm 0.20$ & $0.1370 \pm 0.0092$ & $3.43 \pm 0.23$ & $226.7 \pm 20.7$ \\
\hline 14 & $\mathrm{a}$ & $\mathrm{a}$ & $\mathrm{a}$ & $\mathrm{a}$ \\
\hline 13 & $\mathrm{a}$ & $\mathrm{a}$ & $\mathrm{a}$ & $\mathrm{a}$ \\
\hline 12 & $\mathrm{a}$ & $\mathrm{a}$ & $\mathrm{a}$ & $\mathrm{a}$ \\
\hline 11 & $\mathrm{a}$ & $\mathrm{a}$ & $\mathrm{a}$ & $\mathrm{a}$ \\
\hline Untreated fiber & $7.18 \pm 0.26$ & $0.1402 \pm 0.0219$ & $3.46 \pm 0.54$ & $232.7 \pm 15.0$ \\
\hline
\end{tabular}

a: no clean fiber was successfully reclaimed

\section{SCANNING ELECTRON MICROSCOPY (SEM) ANALYSIS}

SEM is used to investigate the surface of the reclaimed fibers conditioned under various acid concentrations. It also allows the diameter of the carbon fibers to be measured directly for strength calculation. Figure 3 shows the SEM images of the reclaimed carbon fibers under the magnification of $3000 \times$. No residue was observed on the surface of the carbon fibers for solvolysis using concentrated acid of $18 \mathrm{M}$. This confirms that a clean fiber has been successfully reclaimed where all the epoxy resin was fully decomposed during the process. On the other hand, residues of epoxy resin can be clearly observed on the surface of the carbon fiber in $15 \mathrm{M}$ and $16 \mathrm{M}$ acid concentrations while only a small amount of resin is present in $17 \mathrm{M}$. In contrast, the micrograph of the untreated fibers, shows rough regions with significant resin adhering to it. These SEM observations demonstrate the effectiveness of the acid concentrations towards the decomposition of the epoxy resin. 

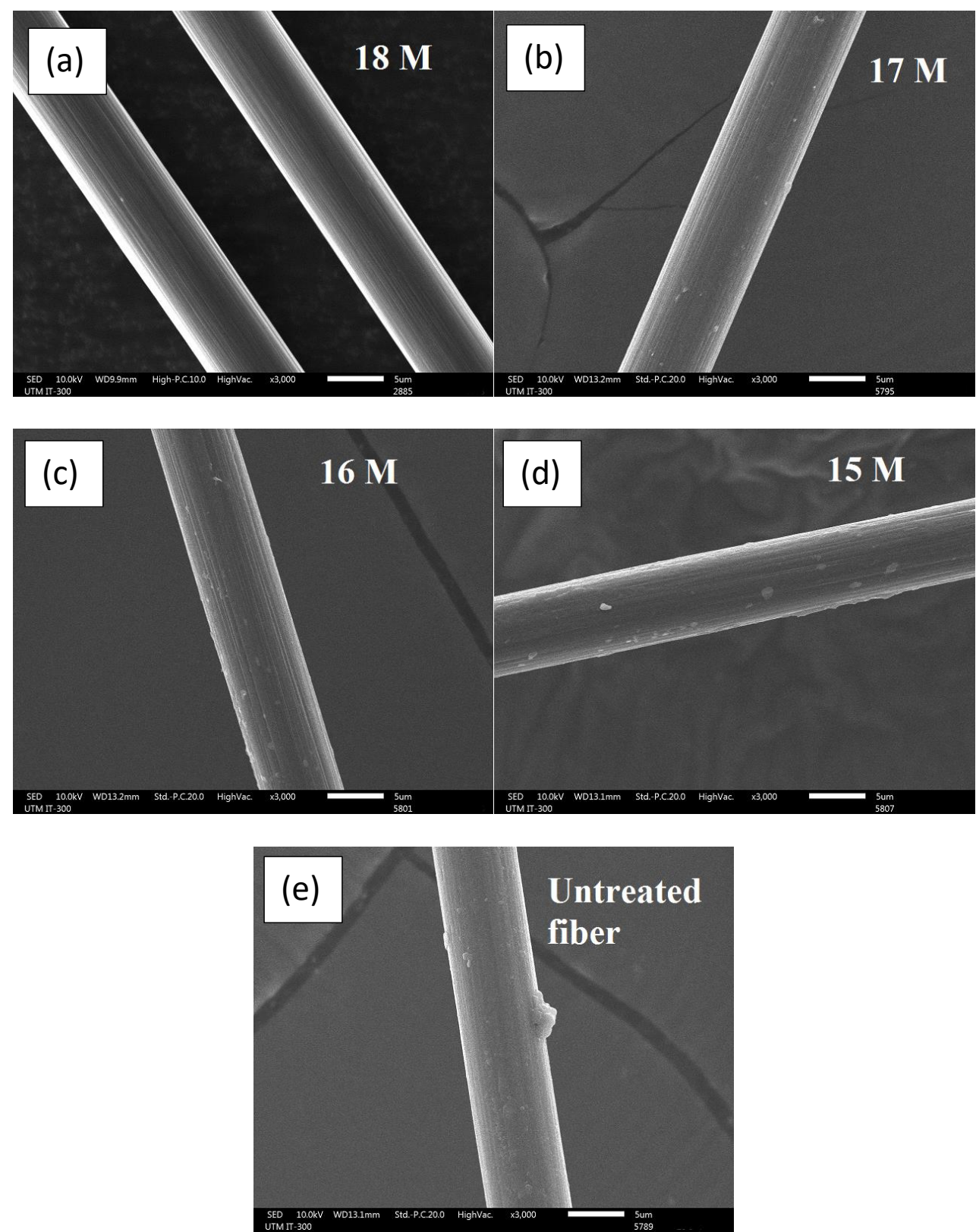

FIGURE 3. SEM micrographs of reclaimed carbon fibers using solvolysis at various acid concentrations: (a) $18 \mathrm{M}$, (b)

$17 \mathrm{M}$, (c) $16 \mathrm{M}$, (d) $15 \mathrm{M}$, and (e) untreated fiber extracted from the composite prepreg

Figure 4 shows the photographs of composites after the solvolysis process at much lower concentrations of 11,12 , 13 , and $14 \mathrm{M}$. For these cases, the resin is still intact and holds the carbon fibers firmly without any sign of partial disintegration. This indicates that acid concentrations lower than $15 \mathrm{M}$ are not effective for decomposing the resin from the composites under room temperature and atmospheric pressure. No further analyses were done on these samples. 

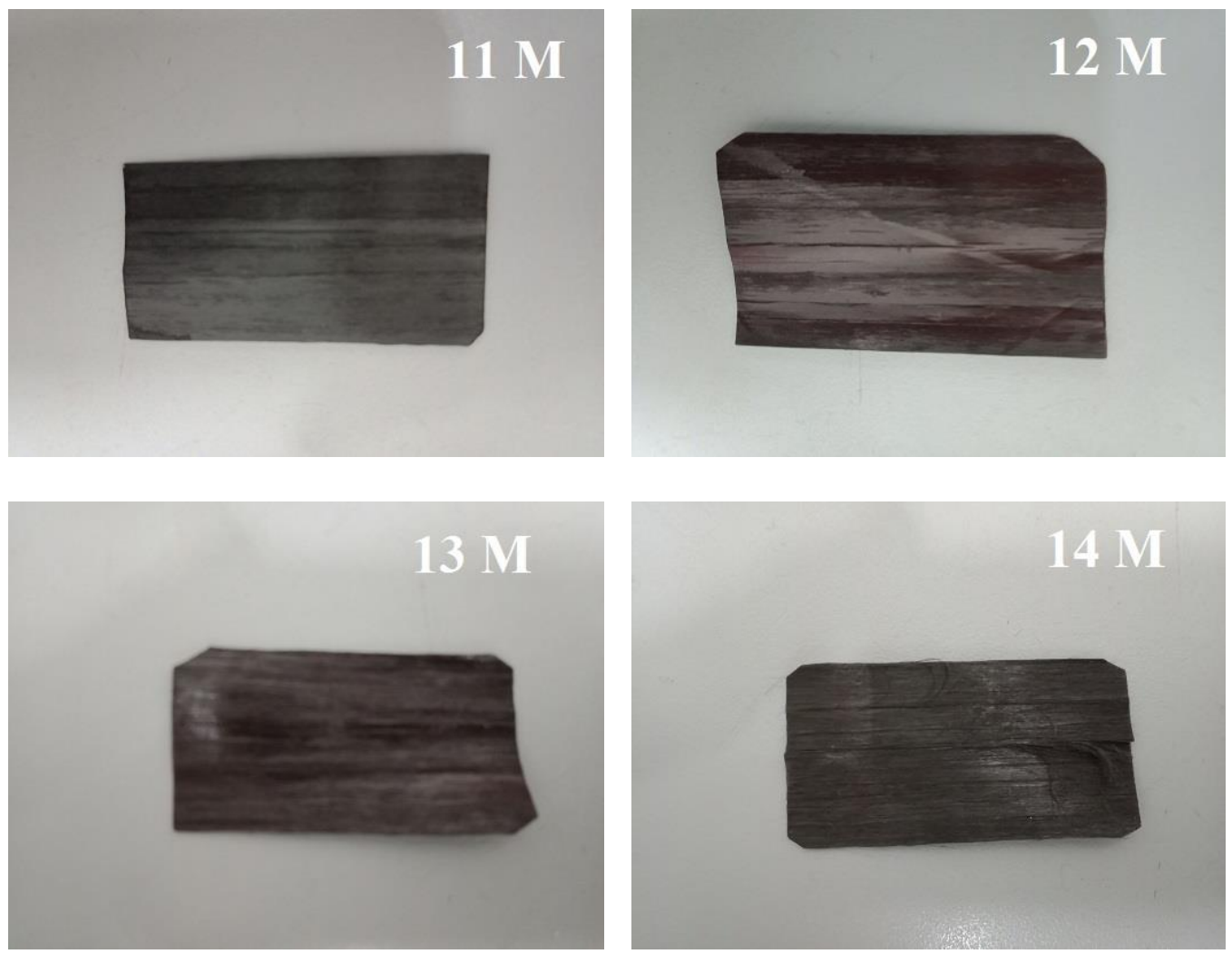

FIGURE 4. Photographs of solvolysis of carbon fiber composites using lower concentrations of sulphuric acid: (a) $11 \mathrm{M}$, (b) $12 \mathrm{M}$, (c) $13 \mathrm{M}$, and (d) $14 \mathrm{M}$

\section{CONCLUSION}

The main objective of this work was to determine the lowest sulphuric acid concentration which can remove the epoxy resin from the carbon fiber reinforced composites, at room temperature and atmospheric pressure. Sulphuric acid of concentration between 18 and $11 \mathrm{M}$ was used in the solvolysis study of CFRP. It was shown that the removal of epoxy resin from CFRP increases with increasing concentration. At $18 \mathrm{M}$, almost all of the epoxy resin has been removed, giving a similar result to that obtained from TGA analysis which is $69.9 \%$ mass retention. However, at $14 \mathrm{M}$ and below, epoxy resin removal was not successful at the given conditions. The single fiber tensile test of the reclaimed fibers also showed the tensile strength and Young's modulus increase with decreasing sulphuric acid concentration. At $15 \mathrm{M}$, the tensile strength and Young's modulus retention were 99.1 and $97.4 \%$, respectively, compared to the untreated carbon fiber. No epoxy residue was observed on the surface of the carbon fibers in $18 \mathrm{M}$ acid, but the amount of epoxy residue slightly increased at lower concentrations. From the results, $15 \mathrm{M}$ sulphuric acid concentration gives the optimal condition to obtain reclaimed carbon fibers based on tensile properties retention and epoxy resin decomposition. The study has shown the feasibility of solvolysis using concentrated sulphuric acid to reclaim the carbon fibers from the epoxy composites under room conditions and future studies will be looked into using concentration of sulphuric acid lower than $15 \mathrm{M}$ for a longer period of time.

\section{ACKNOWLEDGEMENTS}

The authors would like to express their appreciation for the support of the FRGS grants from the Ministry of Education, Malaysia with Project No FRGS/1/2019/TK09/ USMC/02/1 and Project No 5F002 and TDR grant with Project No 07G24.

\section{REFERENCES}

Asmatulu, E., Twomey, J. \& Overcash, M. 2014. Recycling of fiber-reinforced composites and direct structural composite recycling concept. Journal of Composite Materials 48(5): 593-608. 
Bai, Y., Wang, Z. \& Feng, L. 2010a. Chemical recycling of carbon fibres reinforced epoxy resin composites in oxygen in supercritical water. Materials and Design 31: 999-1002.

Bai, Y., Wang, Z. \& Feng, L. 2010b. Interface properties of carbon fiber/epoxy resin composite improved by supercritical water and oxygen in supercritical water. Materials and Design 3: 1613-1616.

Cunliffe, A.M., Jones, N. \& Williams, P.T. 2003. Recycling of fibre-reinforced polymeric waste by pyrolysis: Thermo-gravimetric and bench-scale investigations. Journal of Analytical and Applied Pyrolysis 70: 315-338.

Dang, W., Kubouchi, M., Yamamoto, S., Sembokuya, H. \& Tsuda, K. 2002. An approach to chemical recycling of epoxy resin with amine using nitric acid. Polymer 43: 2953-2958.

Das, M. \& Varughese, S. 2016. A novel sonochemical approach for enhanced recovery of carbon fiber from CFRP waste using mild acid-peroxide mixture. ACS Sustainable Chemistry \& Engineering 4: 2080-2087.

Deng, J., Xu, L., Zhang, L., Peng, J., Guo, S., Liu, J. \& Koppala, S. 2019. Recycling of carbon fibers from CFRP waste by microwave thermolysis. Processes 7(207): 1-12.

Holmes, M. 2014. Global carbon fibre market remains on upward trend. Reinforced Plastics 58(6): 38-45.

Jiang, G. \& Pickering, S.J. 2016. Structure-property relationship of recycled carbon fibres revealed by pyrolysis recycling process. Journal of Material Science 51: 19491958.

Jiang, J., Deng, G., Chen, X., Gao, X., Guo, Q., Xu, C. \& Zhou, L. 2017. On the successful chemical recycling of carbon fiber/ epoxy resin composites under mild condition. Composites Science and Technology 151: 243-251.

Jiang, G., Pickering, S.J., Lester, E.H., Turner, T.A., Wong, K.H. \& Warrior, N.A. 2009 Characterisation of carbon fibres/ epoxy resin composites using supercritical $n$-propanol. Composites Science and Technology 69: 192-198.

Ismail, N.H., Mohammad, M.H.B. \& Jaafar, M. 2018. Multiwalled carbon nanotubes/woven kenaf fabric-reinforced epoxy laminated composites. Sains Malaysiana 47(3): 563-569.

Keith, M.J., Ingram, A. \& Leeke, G.A. 2018. Recycling carbon fibre with an acetone/water solvent and zinc chloride catalyst: Resin degradation and fibre characterization. In SAMPE Europe Conference. Southampton, UK. 11-13 September.

Kouparitsas, C.E., Kartalis, C.N., Varelidis, P.C., Tsenoglou, C.J. \& Papaspyrides, C.D. 2002. Recycling of the fibrous fraction of reinforced thermoset composites. Polymer Composites 23: 682-689.

Li, X., Bai, R. \& McKechnie, J. 2016. Environmental and financial performance of mechanical recycling of carbon fibre reinforced polymers and comparison with conventional disposal routes. Journal of Cleaner Production 127: 451-460.

Meng, F., McKechnie, J., Turner, T.A. \& Pickering, S.J. 2017. Energy and environmental reuse of fluidized bed recycled carbon fibres. Composites: Part A 100: 206-214.

Mohd Ishak, Z.A. 2019. Recycled carbon fibre: A promising future. eXPRESS Polymer Letters 13(12): 1026-1026.
Oliveux, G., Dandy, L.O. \& Leeke, G.A. 2015. Current status of recycling carbon fibre reinforced polymers: Review of technologies, reuse and resulting properties. Progress in Materials Science 72: 61-99.

Onwudili, J.A., Insura, N. \& Williams, P.T. 2013. Autoclave pyrolysis of carbon reinforced composite plastic waste from carbon fibre and chemicals recovery. Journal of the Energy Institute 86(4): 227-232.

Palmer, J., Savage, L., Ghita, O.R. \& Evans, K.E. 2010. Sheet moulding compound (SMC) from carbon fibre recyclate. Composites: Part A 41: 1232-1237.

Palmer, J., Ghita, O.R., Savage, L. \& Evans, K.E. 2009. Successful closed-loop recycling of thermoset composites. Composites: Part A 40: 490-498.

Pickering, S.J. 2006. Recycling technologies for thermoset composite materials-current status. Composites: Part A 37: 1206-1215.

Princaud, M., Aymonier, C., Loppinet-Serani, A., Perry, N. \& Sonnemann, G. 2014. Environmental feasibility of the recycling of carbon fibers from CFRPs by solvolysis using supercritical water. Sustainable Chemistry \& Engineering 2: 1498-1502.

Rybicka, J., Tiwari, A. \& Leeke, G.A. 2016. Technology readiness level assessment of composites recycling technologies. Journal of Cleaner Production 112: 1001-1012.

Shibata, K., Nakagawa, M., Quitain, A. \& Sasaki, M. 2013. CFRP recycling using depolymerization of acid anhydride cured epoxy resin. In 9th International Conference on Composite Materials, Proceedings. pp. 8511-8518.

$\mathrm{Su}$, D.H. 2014. Application of fiber reinforced composites for sports instruments. Applied Mechanics and Materials 687691(2014): 4256-4259.

Vazquez-Moreno, J.M., Sanchez-Hidalgo, R., Sanz-Horcajo, E., Vina, J., Verdejo, R. \& Lopez-Manchado, M.A. 2019. Preparation and mechanical properties of grapheme/ carbon fiber-reinforced hierarchical polymer composites. Journal of Composite Science 3(30): 1-8.

Wang, Y., Cui, X., Ge, H., Yang, Y., Wang, Y., Zhang, C., Li, J., Deng, T., Qin, Z. \& Hou, X. 2015. Chemical recycling of carbon fiber reinforced epoxy resin composites via selective cleavage of the carbon-nitrogen bond. ACS Sustainable Chemistry \& Engineering 3: 3332-3337.

Witik, R.A., Teuscher, R., Michaud, V., Ludwig, C. \& Manson, J.E. 2013. Carbon fibre reinforced composite waste: An environment assessment of recycling, energy recovery and landfilling. Composites: Part A 49: 89-99.

Yan, H., Lu, C., Jing, D. \& Hou, X. 2014. Chemical degradation of amine-cured DGEBA epoxy resin in supercritical 1-propanol for recycling carbon fiber from composites. Chinese Journal of Polymer Science 32: 1550-1563.

Yang, P., Zhou, Q., Li, X.Y., Yang, K.K. \& Wang, Y.Z. 2014. Chemical recycling of fiber-reinforced epoxy resin using a polyethylene glycol/NaOH system. Journal of Reinforced Plastics \& Composites 33(22): 2106-2114.

Zhao, J., Li, G., Wang, Z. \& Zhao, X.L. 2019. Fatigue behavior of concrete beams reinforced with glass and carbon-fiber 
reinforced polymer (GFRP/CFRP) bars after exposure to elevated temperatures. Composite Structures 229(2019): $1-18$.

Muhammad Falaq Muhammad Faisal \& Azman Hassan* School of Chemical and Energy Engineering Faculty of Engineering

Universiti Teknologi Malaysia

81310 UTM Skudai, Johor Darul Takzim

Malaysia

Khong Wui Gan

University of Southampton Malaysia

79200 Iskandar Puteri, Johor Darul Takzim

Malaysia
Mohd Nazrul Roslan \& Azrin Hani Abdul Rashid

Department of Mechanical Engineering Technology

Faculty of Engineering Technology

Universiti Tun Hussein Onn Malaysia

84600 Pagoh, Johor Darul Takzim

Malaysia

*Corresponding author; email: azmanh@cheme.utm.my

Received: 15 January 2020

Accepted: 10 May 2020 